\title{
Residents Coping Strategies with Water Scarcity in Makurdi Town, Nigeria
}

\author{
Ahile, Stephen lorlumun \\ Department of Geography, College of Advanced and Professional Studies, Makurdi \\ Email:steveahile@gmail.com \\ Udoumoh, Enobong Francis \\ Department of Mathematics/Statistics/Computer Science, Federal University of Agriculture, Makurdi \\ Adzande, Patience \\ Department of Urban and Regional Planning, Benue State University, Makurdi
}

Doi:10.5901/mjss.2015.v6n4s2p100

\section{Abstract}

This paper examines the degree of water scarcity across Makurdi town as well as the strategies employed by residents to cope with the problem. Data was gathered via questionnaire administered to 228 respondents mainly household heads (both male and female) who were randomly selected. The results reveal that total household water demand in Makurdi town is estimated at 127,600 Ipd more than the actual available supply of 40,520 Ipd leading to shortfalls of about 87,080 Ipd. This translates to about $68.2 \%$ of water demand not satisfied by supply. Findings also show that the major coping strategies employed by residents include: dredging dry hand-dug wells to get water (30.2\%), storing water in big containers (26.3\%) and walking long distances to get water $(18.9 \%)$. The Fisher's Exact $\left(F_{\text {exact }}\right)$ statistic was employed to test for association between some sociodemographic variables and the coping strategies adopted by residents. The results reveal no association between level of education and the strategies adopted by residents. The results however shows association between level of income, place of residence and the coping strategies adopted. The Likert scaling was used to investigate the causes of water scarcity in the study area. The failure of public water supply system is widely perceived as the major cause of water scarcity in Makurdi town. The paper recommends that residents should be encouraged to pool resources together to provide water supply projects for their common use.

Keywords: Coping Strategies, Spatial Variation, Water Scarcity, Water Supply, Water Demand.

\section{Introduction}

Water is one of life's necessities that have no substitute. It is the life blood of the biosphere (Falkenmark and Rockstrom,2004). Water is needed to support socio-economic activities such as agriculture, mining, food production and for maintaining healthy ecosystems.

Water scarcity is an imbalance between demand and availability $(F A O, 2010)$ and exists when the demand for water exceeds the supply(Molle and Molinga,2003). Water demand already exceeds supply in many parts of the world, and more areas are expected to experience this imbalance in the near future mostly due to population increase (Abaje et al,2009). It is projected that by 2025, 1.8 billion people will be living in countries or regions with absolute water scarcity, and two- thirds of the world's population could be living under water stressed conditions (UN-Water,2007). Another report projects that by 2030, water demand will exceed supply by $50 \%$ in most developing regions of the world (Negoianu and Goldfaid,2008).

In Nigeria, water scarcity is common virtually in all urban areas. The public water supply is unreliable, intermittent and in most cases inaccessible, thus giving rise to a high dependency on unsafe supplementary sources of water supply(Ocheri,2006) which are susceptible to water borne diseases, the most common being dysentery and typhoid fever. A survey conducted by the Federal Ministry of Water Resources in 2008 showed that about $80 \%$ of residents in Nigeria lacked access to improved drinking water (Ezenwaji et al,2014). With the number of surface water bodies and groundwater resources available to the country, water shortages should ideally not be a problem for the nation. The case is unfortunately different.

Benue State is faced with serious water scarcity problems. Reports show for example that Makurdi metropolis has 
a mean household water demand and consumption of 260,404 (Lpd) and 122,698 (Lpd) respectively. This translates to $47 \%$ of the water requirements satisfied by supply (Ocheri,2006). This clearly indicates that there is domestic water scarcity in Makurdi.

To address the problem of water scarcity, the Benue State government established the Benue State Water Board, Benue State Water Supply and Sanitation Agency, Ministry of Water Resources and Environment. These agencies are responsible for providing water and alleviating water supply problems in the state. The government in 2008 also completed and commissioned the Greater Makurdi Water Works, with an estimated water supply capacity of about 100,000 cubic meters per day. Yet, all these efforts have yielded little results. Hence the problem of water scarcity still persists in Makurdi.

Previous studies have mainly assessed water supply situation in different parts of the State. Agbehi(2007), assessed domestic water supply in Ugbokolo Community; Ifan(2002) looked at the problem of water supply in Mbatiav district in Gboko LGA, Aper and Agbehi(2011) examined the determining factors of rural water supply pattern in Ugbokolo Community. Ocheri(2006) analysed water consumption patterns in Makurdi. The common finding among these studies is that water scarcity is prevalent in Benue State. Despite this, little or no attempt has been made in the literature to extensively study the way residents cope with the problem of water scarcity in Makurdi town, and this is where this study derives its relevance. The study therefore has the following objectives:

(a) To determine the degree and spatial variation of water scarcity across Makurdi town.

(b) To investigate residents' perception of the causes of water scarcity in the study area.

(c) To determine the strategies residents adopt to cope with water scarcity in Makurdi town.

(d) To investigate the association between socio-demographic characteristics of respondents and the strategies they adopt to cope with water scarcity.

The findings of this study should help policy makers and intervention agencies understand the various dimensions to the water scarcity problem. This should help in the formulation of policies geared towards sustainable water supply so as to reduce the sufferings of the people.

\section{Literature Review}

Water is a natural resource of fundamental importance. It is a basic need that has become the dominant development priority for most countries especially in the developed parts of the world. Water supports all forms of life and creates jobs and wealth in the water sector, tourism, recreation and fisheries (Ntengwe,2005 cited in Abaje et al,2009). Unfortunately, most countries do not have sufficient water resources to meet reasonable per capital water needs for their rapidly expanding population. It is documented that less than ten countries have about $60 \%$ of globally accessible water (Swaminathan,2001), suggesting inequitable distribution of water globally and nationally, indicating the scarcity of the resource. Water scarcity is the lack of access to adequate quantities of water for human and environmental uses, and it is increasingly being recognised in many countries as a serious and growing concern (White,2012). The scarcity of water affects all social and economic sectors and threatens the sustainability of the natural resource base (UN Water,2007). More importantly, the scarcity of water is capable of affecting the dignity and well- being of a people. The International Water Management Institute (IWMI) has classified water scarcity on the basis of two contexts. These include: physical water scarcity and economic water scarcity.

Physical water scarcity occurs when water availability is limited by natural availability (Molle and Molinga,2003). It can be referred to as a situation where there is not enough water to meet all the demands of the population. Economic water scarcity refers to a situation where there is not enough human, institutional, and financial capital to facilitate access to water even though the water is naturally available to meet human demands. It is largely caused by lack of investment in managing water resources or insufficient human capacity to satisfy the demands of water.

Most developing countries, particularly those in Africa suffer from economic water scarcity. There is very little investment in water projects leading to gross shortfalls in water supply. Where these projects exist, water supply is erratic and inconsistent. Shortage of water supply has largely contributed to water scarcity in most parts of Africa. Evidence from the literature show that only a small percentage of the population have access to portable water supplies (Ndabula and Jidauna,2010; John-Dewole,2012;Galadima et al,2011). Drought occasioned by low rainfall is also a cause of water scarcity. Musemwa (2008), cited in Mukuhlani and Mandlenkosi(2014), reports that the recurring droughts experienced in the past two decades in Balawayo (a city in Zimbabwe) has negatively affected its water resources, leading to shortfalls in water supply. Ndabula and Jidauna (2010) have also attributed the water scarcity problem in most parts of the SudanoSahelian region of Nigeria to recurring drought.

Population growth also causes water scarcity. Rockstrom (2001) argued that population growth is directly or 
indirectly expected to shift about $55 \%$ of the World's population towards severe water scarcity over the next generation. Increase in population is expected to put pressure on available water resources. White (1976) cited in Eja et al(2011), observed that in cities of the developing countries, the state of water provision and expansion of water projects does not match the scale and rate of population and urban growth. A study conducted by Uzima (1990) in Enugu town in eastern Nigeria supports this claim. Findings showed that the water supply development of the town is not commensurate with its population growth. The city has therefore been characterised by recurrent water scarcity.

The water available for human use is also shrinking because pollution from agriculture, industry, and other human activities is degrading the water quality in many rivers, lakes, streams and even groundwater sources which most people depend on (Galadima et al,2011;Ocheri et al,2012). In developing countries, $90-95 \%$ of sewage and 70\% of industrial waste are dumped into surface water where they pollute the water to be supplied(UNFPA,2001 cited in Kholisa,2006). This often overwhelms the municipal treatment capacity. A study conducted by Kimani and Ngindu(2007) in Kenya, reveals that the severe contamination of water is largely due to the close distance between pit latrines and wells. As more water sources become polluted, people are likely to face serious water scarcity problems. Other studies have attributed water scarcity to Increased temperatures and Rising levels of water consumption.

Coping with water scarcity means living in harmony with the environmental conditions specific to and dictated by limited available water resources (Pereira et al, 2009).It involves employing diverse measures or techniques to meet the water needs of the people. The major challenge in addressing water scarcity in Nigeria is the lack of investment in water provision. Water scarcity is deeply rooted in the inadequacy of water supply which is driven mainly by the central government. The supply of water hardly meets people's demand for it. To this end, Ishaku et al (2011), advocates the need for a paradigm shift from public monopoly of water supply to innovative approaches such as rainwater harvesting. Shipek (2007) suggest that people should be educated on how to use technology and to shape landscape to harvest water . This is largely because of the merits associated with this method of water supply. Community participation in water provision has also been advocated as a way out of the water scarcity problem (Kholisa,2006). This involves people pooling resources together to provide water projects. These approaches and many more may not be the panacea for water scarcity, but they offer proof that people can take practical steps today to cope with water scarcity.

\section{Materials and Methods}

\subsection{Description of the study area}

Makurdi lies between latitudes 7037' and 7047' North and longitude 8027' and 8040' East (see figure 1 below). Makurdi is drained by the River Benue which bisects the town into two parts-north and south banks. . Other minor rivers that drain the town, and in turn empty their waters in the River Benue includes: Rivers Idye, Genebe, Urudu, Kpege and Kereke. These rivers are highly seasonal and dry up in the dry season with some stagnant pools in their channels in the dry season. Due to the general low relief of Makurdi, sizeable portions of the area is waterlogged and flooded during heavy rainstorm.

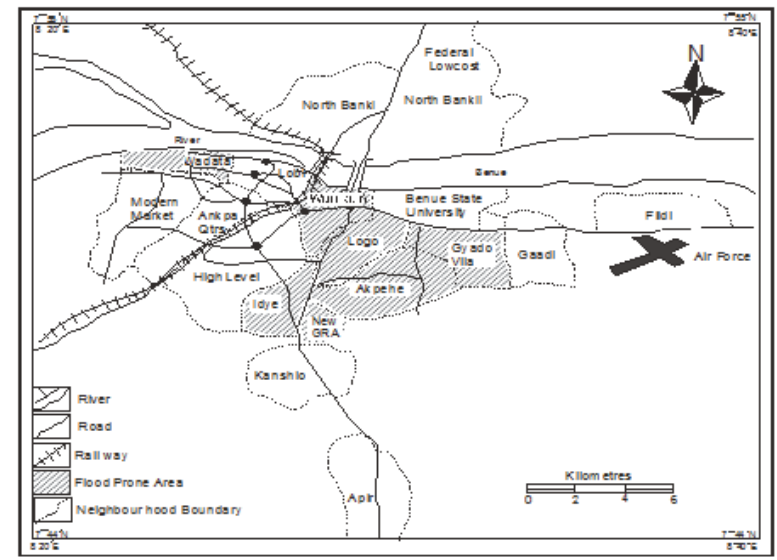

Figure 1. Map Showing Areas in Makurdi Town

Source: Benue State Ministry of Lands and Survey 
The climate is hot and humid which corresponds with Koppen's 'Aw' climate classification . Temperatures are generally high throughout the year due to the constancy of insolation with the maximum of $33^{\circ} \mathrm{C}$ and a mean minimum of $22.5^{\circ} \mathrm{C}$ with annual range of $10.5^{\circ} \mathrm{C}$. Temperatures may occasionally climb to $37^{\circ} \mathrm{C}$ in some days in March and April (Iorkua,2006).Humidity is high all year round. The rainfall of the area is highly seasonal, coming in form of intense, violent, convectional showers of short duration. The geology of Makurdi town is of cretaceous and consists of fluviodeltaic sediments with well-bedded sandstones which are of hydrogeological significance in terms of groundwater yield and exploitation (Kogbo et al, 1978).

\subsection{Data collection and analysis}

The study utilised both primary and secondary data. Secondary data was sourced from the literature, while primary data was sourced using a structured questionnaire which was administered to 228 household heads (both male and female), who were randomly selected. The questionnaire was designed to elicit information on socio-demographic characteristics of respondents, sources of water available to households, distance covered to get water and their perception of the causes of water scarcity. Respondents were also asked to estimate the quantity of water actually consumed (supply) and water needed (demand) in paint bucket (20 litres of liquid content). This is because the paint bucket is a common container used by residents to fetch water in Makurdi town. The number of buckets used was then converted to litres. The estimated difference between water actually consumed and water needed was regarded as the shortages. The instrument was also used to get information on the strategies respondents adopt to cope with water scarcity. The Fisher's Exact statistics (using Monte Carlo method with 10,000 samples) was used to determine the association between sociodemographic characteristics of respondents and the strategies they adopt to cope with water scarcity. The Fisher's Exact statistic was adopted because some of the expected count in the contingency table are less than 5 (Agresti,1992). Other results were presented using descriptive statistics and a Likert scale of Strongly Agree, Agree, Disagree and Strongly Disagree.

\section{Results and Discussion}

\subsection{Socio-demographic Characteristics of Respondents}

Table 1 below shows the vital statistics of the respondents involved in the study. Findings reveal that about $35.5 \%$ of the households have between 2-4 residents,53.5\% have between 5-10 residents, 7\% have between $11-15$ residents, while $3.9 \%$ have more than 16 residents. For gender, $62.7 \%$ are male while $37.3 \%$ are female. Results show that $39 \%$ are below 30 years, $34.6 \%$ are between the ages of $31-40,14.9 \%$ are between the ages of $41-50,8.3 \%$ are between the ages of $51-60$, while $3.1 \%$ age over 60 years. Results also show that $1.8 \%$ have no formal education, $3.9 \%$ have primary education, $25.4 \%$ have secondary education, while $68.9 \%$ have tertiary education. For occupation, $39.5 \%$ are civil servants, $4.4 \%$ are farmers, $5.7 \%$ are artisans, $21.9 \%$ are traders, $28.1 \%$ are unemployed, while $4.0 \%$ have retired. The findings finally reveal that $43.0 \%$ earn less than 20,000 naira monthly,25.9\% earn between $21,000-50,000$ naira monthly,19.3\% earn between 51,000-100,000 naira monthly, while $11.8 \%$ earn more 100,000 naira monthly.

Table 1: Socio- demographic characteristics of respondents.

\begin{tabular}{|c|c|c|c|c|c|}
\hline Gender & $F$ & $\%$ & Marital Status & $F$ & $\%$ \\
\hline Male & 143 & 62.7 & Single & 103 & 45.2 \\
\hline Female & 85 & 37.3 & Married & 125 & 54.8 \\
\hline Total & 228 & 100 & Total & 228 & 100 \\
\hline Age & $\mathrm{F}$ & $\%$ & Education & $\mathrm{F}$ & $\%$ \\
\hline$<30$ & 89 & 39.0 & No formal & 4 & 1.8 \\
\hline $31-40$ & 79 & 34.6 & Primary & 9 & 3.9 \\
\hline $41-50$ & 34 & 14.9 & Secondary & 58 & 25.4 \\
\hline $51-60$ & 19 & 8.3 & Tertiary & 157 & 68.9 \\
\hline Above 60 & 7 & 3.1 & & & \\
\hline Total & 228 & 100 & Total & 228 & 100 \\
\hline Income & $\mathrm{F}$ & $\%$ & Family Size & $\mathrm{F}$ & $\%$ \\
\hline$>20000$ & 98 & 43.0 & $2-4$ & 81 & 35.5 \\
\hline $21000-50000$ & 59 & 25.9 & $5-10$ & 122 & 53.5 \\
\hline $51000-100000$ & 44 & 19.3 & $11-15$ & 16 & 7.0 \\
\hline Above 100000 & 27 & 11.8 & $16+$ & 9 & 3.9 \\
\hline Total & 228 & 100 & Total & 228 & 100 \\
\hline
\end{tabular}




\subsection{Sources of Water Supply in Makurdi Town}

The water sources available to households in Makurdi town include public taps, boreholes, rainwater, hand-dug wells, rivers/streams, water vendors and from neighbours. From table 2 below, findings show that about $11 \%$ and $7 \%$ of households get water from public taps in the rainy and dry season respectively. Boreholes contribute $9.2 \%$ and $12.3 \%$ of water supply to households in the rainy and dry season respectively. Responses also show that $42.5 \%$ and $43 \%$ obtain water from hand-dug wells in the rainy and dry season respectively. This indicates that majority of the respondents depend on hand dug wells for water. It was observed that most of these wells were neatly covered and protected. Rainwater contributes about $31.1 \%$ in the rainy season, while this source contributes nothing in the dry season, primarily because of the absence of rainfall. Rivers/streams contribute only about $1.3 \%$ and $3.5 \%$ of water supply to households in the rainy and dry season respectively. Also, $1.3 \%$ and $2.2 \%$ of respondents get water from neighbours in the rainy and dry season respectively. Responses also show that about 3.5\% and 32\% get water from vendors in the rainy and dry season respectively.

Table 2: Water supply sources available to households in the dry and rainy seasons.

\begin{tabular}{|c|c|c|}
\hline Source & Rainy season & Dry season \\
\hline Rain water & $71(31.1 \%)$ & $0(0 \%)$ \\
\hline Public tap & $25(11.0 \%)$ & $16(7.0 \%)$ \\
\hline Borehole & $21(9.2 \%)$ & $28(12.3 \%)$ \\
\hline Hand dug well & $97(42.5 \%)$ & $98(43.0 \%)$ \\
\hline River/stream & $3(1.3 \%)$ & $8(3.5 \%)$ \\
\hline From neighbour & $3(1.3 \%)$ & $5(2.2 \%)$ \\
\hline Water vendors & $8(3.5 \%)$ & $73(32.0 \%)$ \\
\hline Total & $228(100 \%)$ & $228(100 \%)$ \\
\hline
\end{tabular}

Source: Authors Fieldwork, 2015

\subsection{Causes of Water Scarcity in Makurdi Town}

To find out residents perception of the causes of water scarcity in Makurdi, respondents were initially asked if they experienced water scarcity in their households. From table 3 below, the results show that $72.8 \%$ responded to the affirmative, while $27.2 \%$ said they don't experience water scarcity. This indicates that there is water scarcity in Makurdi.

Table 3: Do you experience water scarcity or not?

\begin{tabular}{|c|c|c|}
\hline Response & $F$ & $\%$ \\
\hline Yes & 166 & 72.8 \\
\hline No & 62 & 27.2 \\
\hline Total & 228 & $100 \%$ \\
\hline
\end{tabular}

Source: Authors Fieldwork, 2015

Generally, water scarcity is known to be caused by factors such as climate change, population increase, water pollution, among others. Table 4 below summaries the results obtained of the causes of water scarcity in Makurdi. The findings show that $78.5 \%$ of the respondents strongly agreed and $7.8 \%$ agreed that failure of public water supply system is the causes of water scarcity in Makurdi. However, $3.5 \%$ and $10.1 \%$ disagree and strongly disagree respectively. These respondents are likely to be from Lobi Quarters and High Level, areas which periodical get water supply from the Water Board. Population increase/ growth is also noted to be responsible for water scarcity in Makurdi as indicated by $10.5 \%$ and $17.1 \%$ of the respondents who strongly agreed and agreed respectively. However, $14.5 \%$ and $57.9 \%$ of the respondents disagreed and strongly disagreed respectively. It is observed that apart from the Failure of Public Water Supply System, a greater percentage of the respondents disagreed and strongly disagreed that the other factors were responsible for water scarcity in Makurdi. This indicates that the failure of the public water supply system is the major cause of water scarcity in Makurdi. Samantha(2011) also reports that poor management of water supply and water 
resources in general is the major cause of the water crises in Kenya. In Benue State, successive governments have not done enough to meet the water needs of the people. There has been an increased need for funding, improved management and development of water resources to meet up with the growing population. The old Makurdi water works presently used does not have the capacity to meet this need. Unfortunately, even the newly constructed 'Greater Makurdi' water works commissioned over four years ago is not yet fully operational.

Table 4: Perception of the causes of water scarcity in Makurdi town.

\begin{tabular}{|l|c|c|c|c|}
\hline Causes & Strongly agree & Agree & Disagree & Strongly disagree \\
\hline Population increase & $24(10.5 \%)$ & $39(17.1 \%)$ & $33(14.5 \%)$ & $132(57.9 \%)$ \\
\hline Failure of public water supply system & $179(78.5 \%)$ & $18(7.9 \%)$ & $8(3.5 \%)$ & $23(10.1 \%)$ \\
\hline Water pollution & $12(5.3 \%)$ & $32(14.0 \%)$ & $40(17.5 \%)$ & $144(63.2 \%)$ \\
\hline Poor water usage & $11(4.8 \%)$ & $19(8.3 \%)$ & $47(20.6 \%)$ & $151(66.2 \%)$ \\
\hline Decreased groundwater levels & $19(8.3 \%)$ & $31(13.6 \%)$ & $30(13.2 \%)$ & $148(64.9 \%)$ \\
\hline Decreased rainfall & $16(7.0 \%)$ & $30(13.4 \%)$ & $35(15.4 \%)$ & $147(64.5 \%)$ \\
\hline Increased water consumption & $27(11.8 \%)$ & $31(13.6 \%)$ & $28(12.3 \%)$ & $142(62.3 \%)$ \\
\hline Total & $228(100 \%)$ & $228(100 \%)$ & $228(100 \%)$ & $228(100 \%)$ \\
\hline
\end{tabular}

Source: Authors Fieldwork, 2015

\subsection{Spatial Variation in Water Scarcity in Makurdi Town}

To determine the spatial variation in water scarcity across Makurdi, the study estimated what quantity of water was needed (demand) and what quantity was actually consumed (supply). The difference was therefore regarded as the deficiency. Table 5 below summarises the information. The findings show that the sampled households across Makurdi have a total water demand and consumption of $127,600 \mathrm{lpd}$ and $40,520 \mathrm{lpd}$ respectively. This follows that there is a shortfall of about 87,080 litres, representing about $68.2 \%$ of water demand not meet by supply. Drawing from the water deficiency situation, the findings further reveal that none of the areas have been able to meet up to $40 \%$ of their water needs. However, households in Lobi quarters and Gyado villa areas of the town are able to meet $39.5 \%$ and $36.2 \%$ of their water needs respectively. The former is connected to the public water supply. This could explain why residents have been able to relatively meet their water needs. Another reason could be the fact that residents are top civil servants and businessmen and have money to drill boreholes and also engage the services of vendors. In the latter, almost all households were observed to have hand- dug wells. This likely explains why residents here are also able to relatively meet their needs.

The water shortage situation in North Bank area appears to be the worst. Households are able to meet only about $22.3 \%$ of their water needs. This area has never been connected to the public water supply, boreholes are hard to come by and even hand- dug wells are relatively few.

Table 5: Estimate of water supply and demand across Makurdi town.

\begin{tabular}{|c|c|c|c|c|c|c|c|}
\hline $\begin{array}{c}\text { Place of } \\
\text { Residence }\end{array}$ & $\begin{array}{c}\text { No. of } \\
\text { households } \\
\text { sampled }\end{array}$ & $\begin{array}{c}\text { Mean water } \\
\text { supply(litres) }\end{array}$ & $\begin{array}{c}\text { Total water } \\
\text { supply (litres) }\end{array}$ & $\begin{array}{c}\text { Mean water } \\
\text { demand (litres) }\end{array}$ & $\begin{array}{c}\text { Total water } \\
\text { demand (litres) }\end{array}$ & Shortfall & $\begin{array}{c}\text { \%Water Demand } \\
\text { Satisfied by Supply }\end{array}$ \\
\hline Gyado villa & 18 & 154.4 & 2780 & 427.7 & 7700 & 4920 & 36.2 \\
\hline Kanshio & 25 & 172.8 & 4320 & 620.8 & 15520 & 11200 & 27.2 \\
\hline Logo & 22 & 169.1 & 3720 & 515.4 & 11340 & 7620 & 32.8 \\
\hline Nyiman & 25 & 85.6 & 2140 & 333.6 & 8340 & 6200 & 26.6 \\
\hline New GRA & 20 & 191 & 3820 & 668 & 13360 & 9540 & 28.6 \\
\hline AnkpaQrts & 22 & 243.6 & 5360 & 790 & 17380 & 12020 & 30.8 \\
\hline Idye & 24 & 201.6 & 4840 & 599.1 & 14380 & 9540 & 33.7 \\
\hline LobiQrts & 23 & 286.1 & 6580 & 724.3 & 16660 & 10080 & 39.5 \\
\hline High level & 25 & 204.8 & 5120 & 587.2 & 14680 & 9560 & 34.9 \\
\hline North bank & 24 & 76.7 & 1840 & 343.3 & 8240 & 6400 & 22.3 \\
\hline Total & 228 & & 40,520 & & 127,600 & $\mathbf{8 7 , 0 8 0}$ & \\
\hline
\end{tabular}

Source: Authors Fieldwork, 2015 


\subsection{Water Scarcity Coping Strategies}

Water scarcity is not unique to Nigeria but exist in most African and Asian countries. Hence people device strategies to cope with the situation. Table 6 below is a summary of the strategies employed by households to cope with water scarcity in Makurdi town. The results reveal that $30.2 \%$ of the respondents usually dredge dry hand-dug wells to get water. This strategy is used mainly in the dry season. Ocheri et al(2010) observed that shallow wells in Makurdi town are full to the brim during the rainy season and could be fetched without the use of ropes and buckets. These wells however dry up as the dry season sets in, forcing people to dig further to get water that will serve them for a while. The findings also show that $26.3 \%$ of the respondents store water in big containers to cope with scarcity. This strategy is adopted both in dry and rainy season. The water is supplied mainly by Tankers and Vendors (Mai ruwa). This invariably affects the income of most household heads. According to Mr. Daniel Aja, a civil servant who resides in the North Bank area of the town, he spends between $5 \%$ and $10 \%$ of his salary monthly on water depending on the season.

Table 6: Strategies employed by residents to cope with water scarcity.

\begin{tabular}{|c|c|c|c|c|c|c|}
\hline \multicolumn{7}{|c|}{ Strategies } \\
\hline & $\begin{array}{l}\text { Rain water } \\
\text { harvesting }\end{array}$ & $\begin{array}{c}\text { Walking long } \\
\text { distances to get water }\end{array}$ & $\begin{array}{l}\text { Dredging dry hand-dug } \\
\text { wells to get water }\end{array}$ & $\begin{array}{l}\text { Minimizing } \\
\text { water use }\end{array}$ & $\begin{array}{l}\text { Storing water in big } \\
\text { containers }\end{array}$ & Total \\
\hline $\mathrm{F}$ & 30 & 43 & 69 & 26 & 60 & 228 \\
\hline$\%$ & 13.2 & 18.9 & 30.2 & 11.4 & 26.3 & $100 \%$ \\
\hline
\end{tabular}

Source: Authors Fieldwork, 2015

Also as a coping strategy, the findings reveal that $18.9 \%$ of the respondents either drive or walk long distances to get water. Table 7 below is a summary of the various distances residents walk to go and get water. The people who walk long distances to fetch water are mainly women and children. Gbolahan and Coster (2012) argue that this can lead to drudgery and consequently impact on the health of these people. In some cases the education of children suffers as they are forced to spend several hours looking for water instead of going to school (Mukuhlani and Mandlenkosi,2014; Uzzia,2010). Rain water harvesting is another strategy employed by some residents to cope with scarcity as indicated by $13.2 \%$ of the respondents. This is the most convenient coping strategy. Water is collected from roof tops and stored in containers for use during the lean periods. This eliminates financial cost and drudgery of water collection. Unfortunately, this strategy is limited to the rainy season. Again $11.4 \%$ of the respondents indicated that they minimise their use of water as a way of coping with scarcity. It is observed that majority of the households combine a number of coping strategies, yet the measures have proved inadequate in addressing their water scarcity problems.

Table 7: Distance covered by residents to get water.

\begin{tabular}{|c|c|c|c|c|c|c|}
\hline \multicolumn{7}{|c|}{ Distance } \\
\hline & $1-200 \mathrm{~m}$ & $201-400 \mathrm{~m}$ & $401-1 \mathrm{~km}$ & $2-4 \mathrm{~km}$ & Above $4 \mathrm{~km}$ & Total \\
\hline $\mathrm{F}$ & 158 & 36 & 22 & 8 & 4 & 228 \\
\hline$\%$ & 69.3 & 15.8 & 9.6 & 3.5 & 1.8 & 100 \\
\hline
\end{tabular}

Source: Authors Fieldwork, 2015

\subsubsection{Association between Socio-Demographic Characteristics of Respondents and Strategies Adopted to Cope with Water Scarcity.}

Evidence of association between some socio-demographic variables (Level of income, Level of education and Place of residence) and strategies employed to cope with water scarcity was explored by contingency tables and tested using the Fisher's Exact statistic at $1 \%$ level of significance. Table 8 below summarises the results. The result reveals no association $\left(F_{\text {exact }}=5.536, \mathrm{df}=12, \mathrm{P}\right.$ - value $\left.=0.961\right)$ between respondents level of education and the strategies employed to cope with water scarcity. However, the results shows an association $\left(F_{\text {exact }}=22.110, \mathrm{df}=12, \mathrm{P}\right.$-value $\left.=.030\right)$ between respondents level of income and the coping strategies employed. This is consistent with Oloukoi et al(2013). This implies that respondent's income will determine the strategies they adopt to cope with water scarcity. The results reveal for 
instance that for respondents who earn less than 20,000 NGN monthly, $35.7 \%$ walk long distances to get water while $8.2 \%$ store water in big containers as a strategy to cope with scarcity. Since most of the water stored in big containers is bought from vendors, these respondents do not have enough money to buy hence they resort to walking long distances to get water. Conversely, for respondents who earn more than 100,000NGN monthly, 37.1\% store water in big containers while only $7.4 \%$ employ walking long distances to get water as a coping strategy.

The association between the respondents place of residence and the strategies they adopt to cope with water scarcity was found to be significant $\left(F_{\text {exact }}=90.231, \mathrm{df}=36, \mathrm{P}\right.$-value $\left.=.000\right)$. In Gyado villa for instance, it was observed that most houses have hand dug wells. This explains why majority (88\%) of the respondents would rather adopt dredging dry wells to get water as a coping strategy rather than walking long distances to get water (4\%). In Lobi quarters, there are less hand-dug wells so there is no need to adopt dredging dry wells to get water as a coping strategy. Lobi quarters is one of the few areas in the town that is connected to public water supply. But since water supply is erratic and inconsistent, residents store water in big containers to use in periods of water shortages.

Table 8: Association between socio-demographic characteristics of respondents and the strategies adopted to cope with water scarcity.

\begin{tabular}{|c|c|c|c|c|c|c|c|}
\hline \multirow[b]{2}{*}{ Variable } & \multicolumn{6}{|c|}{ Coping Strategy Adopted } & \multirow[b]{2}{*}{ Statistic } \\
\hline & $\begin{array}{l}\text { Rain water } \\
\text { harvesting }\end{array}$ & \begin{tabular}{|c|} 
Walking long distance to get \\
water
\end{tabular} & $\begin{array}{l}\text { Dredging dry hand dug wells to } \\
\text { get water }\end{array}$ & $\begin{array}{l}\text { Minimising water } \\
\text { use }\end{array}$ & $\begin{array}{l}\text { Saving water in big } \\
\text { containers }\end{array}$ & Total & \\
\hline \multicolumn{8}{|l|}{ Education } \\
\hline $\begin{array}{l}\text { No formal } \\
\text { education }\end{array}$ & $1(25.0 \%)$ & $1(25.0 \%)$ & $2(50.0 \%)$ & $0(0.0 \%)$ & $0(0.0 \%)$ & $4(100 \%)$ & \multirow{5}{*}{$\begin{array}{c}F_{\text {exact }}= \\
5.536 \\
d f=12 \\
P(0.961)\end{array}$} \\
\hline Primary education & $1(11.1 \%)$ & $2(22.2 \%)$ & $2(22.2 \%)$ & $1(11.1 \%)$ & $3(33.3 \%)$ & $9(100 \%)$ & \\
\hline Secondary & $8(13.8 \%)$ & $13(22.4 \%)$ & $14(24.1 \%)$ & $5(8.6 \%)$ & $18(31.0 \%)$ & $58(100 \%)$ & \\
\hline Tertiary & $20(12.7 \%)$ & $27(17.2 \%)$ & $46(29.3 \%)$ & $20(12.7 \%)$ & $44(28.0 \%)$ & $157(100 \%)$ & \\
\hline Total & $30(13.2 \%)$ & $43(18.9 \%)$ & $64(28.1 \%)$ & $26(11.4 \%)$ & $65(28.5 \%)$ & $228(100 \%)$ & \\
\hline \multicolumn{8}{|l|}{ Monthly Income } \\
\hline$<\mathrm{N} 20,000$ & $15(15.3 \%)$ & $35(35.7 \%)$ & $25(25.8 \%)$ & $15(15.3 \%)$ & $8(8.2 \%)$ & $98(100 \%)$ & \multirow{5}{*}{$\begin{array}{c}F_{\text {exact }}= \\
22.110 \\
d f=12 \\
P(0.030)\end{array}$} \\
\hline $\begin{array}{l}\mathrm{N} 21,000- \\
\mathrm{N} 50,000\end{array}$ & $8(13.6 \%)$ & $7(11.9 \%)$ & $20(33.9 \%)$ & $8(13.6 \%)$ & $16((27.1 \%)$ & $59(100 \%)$ & \\
\hline $\mathrm{N} 51,000-100,000$ & $4(9.1 \%)$ & $9(20.5 \%)$ & $8(18.2 \%)$ & $2(4.5 \%)$ & $21(47.7 \%)$ & $44(100 \%)$ & \\
\hline$>\mathrm{N} 100,000$ & $6(22.2 \%)$ & $2(7.4 \%)$ & $3(11.1 \%)$ & $6(22.2 \%)$ & $10(37.1 \%)$ & $27(100 \%)$ & \\
\hline Total & $30(13.2 \%)$ & $43(18.9 \%)$ & $64(28.1 \%)$ & $26(11.4 \%)$ & $65(28.5 \%)$ & $228(100 \%)$ & \\
\hline \multicolumn{8}{|l|}{ Place of Residence } \\
\hline Gyado villa & $0(0.0 \%)$ & $1(4.0 \%)$ & $22(88.0 \%)$ & $0(0.0 \%)$ & $2(8.0 \%)$ & $25(100 \%)$ & \multirow{11}{*}{$\begin{array}{c}F_{\text {exact }}= \\
90.231 \\
\mathrm{df}=36 \\
\mathrm{P}(.000)\end{array}$} \\
\hline Kanshio & $2(11.1 \%)$ & $3(16.7 \%)$ & $6(33.3 \%)$ & $3(16.7 \%)$ & $4(22.2 \%)$ & $18(100 \%)$ & \\
\hline \begin{tabular}{|l} 
Logo \\
\end{tabular} & $2(9.1 \%)$ & $9(40.9 \%)$ & $5(22.7 \%)$ & $2(9.1 \%)$ & $4(18.2 \%)$ & $22(100 \%)$ & \\
\hline Nyiman & $6(26.1 \%)$ & $7(30.4 \%)$ & $7(30.4 \%)$ & $1(4.3 \%)$ & $2(8.7 \%)$ & $23(100 \%)$ & \\
\hline New GRA & $6(30.0 \%)$ & $4(20.0 \%)$ & $3(15.0 \%)$ & $1(5.0 \%)$ & $6(30.0 \%)$ & $20(100 \%)$ & \\
\hline Ankpa quarters & $7(31.8 \%)$ & $2(9.1 \%)$ & $4(18.0 \%)$ & $1(4.5 \%)$ & $8(36.4 \%)$ & $22(100 \%)$ & \\
\hline Idye & $3(12.5 \%)$ & $5(20.8 \%)$ & $6(25.0 \%)$ & $3(12.5 \%)$ & $7(29.2 \%)$ & $24(100 \%)$ & \\
\hline \begin{tabular}{|l} 
Lobi quarters \\
\end{tabular} & $0(0.0 \%)$ & $4(16.0 \%)$ & $2(8.0 \%)$ & $4(16.0 \%)$ & $15(60.0 \%)$ & $25(100 \%)$ & \\
\hline \begin{tabular}{|l} 
High level \\
\end{tabular} & $1(4.2 \%)$ & $3(12.5 \%)$ & $6(25.0 \%)$ & $4(16.7 \%)$ & $10(41.7)$ & $24(100 \%)$ & \\
\hline North bank & $3(12.0 \%)$ & $5(20.0 \%)$ & $3(12.0 \%)$ & $7(28.0 \%)$ & $7(28.0)$ & $25(100 \%)$ & \\
\hline Total & $30(13.2)$ & $43(18.9)$ & 64 (28.1) & $26(11.4)$ & 65 (28.5) & $228(100 \%)$ & \\
\hline
\end{tabular}

Source: Authors Fieldwork, 2015

\section{Conclusion}

The paper concludes that there is a serious water scarcity problem in Makurdi town; hence residents have devised strategies to cope with the situation. Their efforts however have not sufficiently helped to solve the scarcity problem. The consensus among majority of the residents is that water scarcity is caused mainly by the failure of the public water supply system.

It is recommended that Government should invest more resources into water supply projects; water storage tanks should be constructed and positioned strategically in all areas of the town to ensure people have unhindered access to portable water. Residents are also encouraged to engage in self- help water supply projects by pooling resources together to either sink boreholes or dig wells for their common use. Community involvement in the water management process should also be encouraged. This will help residents to have a sense of responsibility and thus curb the occurrence of vandalism of water equipment. 


\section{References}

Abaje, I.B., Ati,O.F. and Ishaya, S. (2009). Nature of Potable Water Supply and Demand in Jema'a LGA of Kaduna State, Nigeria. Research Journal of Environmental and Earth Sciences, 1(1):16-21.

Agbehi, S.I. (2007). Assessment of domestic water supply in Ugbokolo community, OkpokwuLGA,Benue State. Unpublished M.Sc Project, Department of Geography, Benue State University, Makurdi.

Agresti, A. (1992). A Survey of Exact Inference for Contingency Tables. Statistical Science. 7(1): 131-153.

Eja, E.I., Otu, J.E., Atu, J.E. and Edet, E.O.(2011). Urban Water Supply as a Catalyste for Socio-Economic Transformation of Port Harcourt City, Nigeria. International Journal of Humanities and Social Sciences; 1(2),89-94.

Ezenwaji, E.E., Anyaeze,E., Otti, V.I. and Obienusi, E.A. (2014).Mainfestations of water supply shortages and implication for rural development in Anambra state, Nigeria. Journal of Environmental Sciences and Water Resources. 3(7),pp: 149-155.

Falkenmark, M and Rockstrom, J.(2004). Balancing Water for Human and Nature: The New Approach in Ecology, Earthscan Publication. London.

FAO(2010). Enduring Farms: Climate change, Small holders and Traditional Farming Communities. FAO, Rome.

Galadima, A., Garba,Z.N., Leke,L., Almustapha,M.N. and Adam,I.K. (2011). Domestic Water Pollution among Local Communities in Nigeria: causes and consequences. European Journal of Scientific Research, 52(4),pp.592-603.

Gbolahan, A.O and Coster, A.S.(2012). Impact of Water Scarcity and Drudgery of Water Collection on Women Health in Ogun of Nigeria. Journal of Human Ecology; 39(1):1-9.

Ifan, A.B. (2002). The problem of water supply in Mbatiav district in Gboko LGA of Benue State,Nigeria. Unpublished B.Sc Project, Benue State University, Makurdi, Nigeria.

Iorkua, S.A.(2006). A Study of the Inter- Relationship among Gully Elements in North Bank Makurdi.Journal of Geography and Development,1(1):32-51.

Ishaku, H.T., Rafee Majid,M., Ajayi, A and Haruna, A.(2011). Water Supply Dilemma in Nigerian Rural Communities: Looking towards the Sky for an Answer. Journal of Water Resources and Protection.3,598- 606.

John-Dewole, O.O.(2012). Adverse Effects of Inadequate Water Supply on Human Health: a case study of Kajola Local Government in Oyo State, Nigeria. Greener Journal of Medical Sciences, 2(5),pp.115-119.

Kholisa, S.(2006). The Role of Women in Mitigating Water Scarcity. M.Sc Thesis, Faculty of the Humanities, University of the Free State, Bloemfontein, South Africa.

Kimani-Murage, E.W. and Ngindu, A.M. (2007). Quality of water the Slum Dwellers use: The case of a Kenyan Slum. Journal of Urban Health: Bulletin of the New York Academy of Medicine, 84(6),pp.829-838.

Kogbe, C.A., Torkshi,A., Osujuk, D., and Wozney, D.E.(1978). Geology of Makurdi in the Middle Benue Valley, Nigeria. Occassional Publication of the Department of Geology. Ahmadu Bello University Zaria.

Molle, F. and Mollinga, P.(2003). Water poverty indicators: Conceptual problems and policy issues. Water Policy, 5:529- 532.

Mukuhlani, T. and Mandlenkosi,T.N.(2014). Water Scarcity in Communities, Coping Strategies and Mitigation Measures: The Case of Baluwayo. Journal of Sustainable Development; 7(1).

Ndabula, C. and Jidauna,G.G.(2010). Domestic Water Use in Selected Settlements in the Sudano- Sahelian Region of Nigeria. International Journal of Water and Soil Resources, 1(1),pp. 1-11.

Negoianu, D. and Goldfaid, S.(2008). Just Add Water. Journal of American Society of Nephrology,19(6):1041-1043.

Ocheri, M.(2006). Analysis of Water Consumption Pattern in Makurdi Metropolis. Journal of Geography and Development,1(1):71-83.

Ocheri, M.I., Mile, I.I. and Obeta, M.C.(2010). Seasonal variation of nitrate levels in hand dug wells in Makurdi metropolis. Pakistan Journal of Nutrition; 9, 539- 542.

Ocheri, M., Ahola, O. and Atu, B.(2012). Profile of Water Related Diseases in Benue State, Nigeria. American Journal of Human Ecology, 1(3), pp.87-94.

Oloukoi, G.A., Urmilla, B. and Vadi, M. (2013). Households' coping strategies for climate variability related water shortages in Oke- Ogun region, Nigeria (abstract). Environmental Development, 5:23-38.

Pereira, L.S., Cordery, L. and Lacovides, L.(2009). Coping with water scarcity: Addressing the challenges. New York: Springer.

Rockstrom, J.(2001). Green water security for the food makers of tomorrow: windows for opportunity in drought- prone savannahs, Water Science and Technology,43(4), pp. 71-78.

Shipek,L.(2007).Coping with water scarcity. Available online at hppt://www.csmonitor.com/2007/0405/p09s02-coop.html

Swaminathan, M.S.(2001). Ecology and Equity: Key Determinants of Sustainable Water Security, Water Science and Technology, 43(4),pp.35-44.

UN- Water (2007). Coping with water scarcity-challenge of the 21 st century. World Water Day,2007.

Uzoma, E.C.(1990). Water Supply: A case study of Enugu Metropolis. B.Sc Project, Anambra State University of Technology, Enugu.

Uzzia, P.N.(2010). Water Supply and Children Involvement. Journal of Educational Amenities,3(1),pp.22-29.

White, C.(2012). Understanding water scarcity: Definitions and Measurements, GWF Discussion Paper 1217, Global Water Forum, Canberra, Australia. Available online at:hppt://www.globalwaterforum.org. 